\title{
Antioxidant Activity and Element Content of Suillus collinitus
}

\author{
Celal Bal ${ }^{1, a, *}$

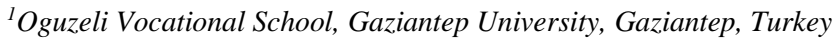 \\ *Corresponding author \\ A R T I C L E I N F O A B S T R A C T \\ Research Article \\ Received : 17/10/2020 \\ Accepted : 21/01/2021 \\ Mushrooms used as food have medicinal importance due to their antioxidant compounds. In this \\ context, it is very important to determine the biological potential of fungi and to reveal these \\ medicinal properties. In this study, it was aimed to determine the element contents, total antioxidant \\ status, total oxidant status, oxidative stress index of Suillus collinitus (Fr.) Kuntze mushroom. In \\ this context, the mushroom samples were extracted with ethanol in the Soxhlet extractor. Element \\ contents were determined using atomic absorption spectrometry. Total antioxidant (TAS) and total \\ oxidant (TOS) levels and oxidative stress index (OSI) were determined using Rel Assay commercial \\ kits. As a result of the study, it was determined that the TAS value of $S$. collinitus was $2.467 \pm 0.145$ \\ $\mathrm{mmol} / \mathrm{L}$, TOS value was $17.845 \pm 0.273 \mu \mathrm{mol} / \mathrm{L}$ and OSI value was $0.677 \pm 0.030$. In addition, the \\ Fe content $(350.72 \pm 10.23), \mathrm{Cu}$ content $(68.11 \pm 2.51), \mathrm{Pb}$ content $(11.58 \pm 2.43), \mathrm{Zn}$ content $(10.46$ \\ Keywords: \\ Suillus collinitus \\ Antioxidant \\ $\pm 1.28)$ and $\mathrm{Ni}$ content $(1.47 \pm 0.21 \mathrm{mg} . \mathrm{kg}-1)$ of $S$. collinitus measured. As a result, S. collinitus \\ mushroom is thought to be a natural source of antioxidants. It has also been observed that the \\ Oxidative stress \\ element contents are at normal levels.
} Element content Medicinal mushroom

\section{Introduction}

A better understanding of the high nutritional value and medicinal importance of mushrooms in recent years has led to an increased interest in mushrooms. In addition to nutritional values, it has been determined that the active ingredients in its content have a therapeutic effect (Arpaz et al., 2017). Many studies have shown that mushrooms have different biological activities. In studies on mushrooms, it has been reported to have many activities such as antioxidant, antitumor, antimicrobial, antiaromatase activity, anti-inflammatory activity, antiproliferative activity and immunomodulatory activity (Akgul et al., 2017; Bal et al., 2017; Kikuchi et al., 2017; Sriramulu and Sumathi, 2017; Wang et al., 2018; Sevindik 2018a; Gürgen et al., 2020; Mushtaq et al., 2020). Turkey has a high diversity in terms of biodiversity. This diversity is increasing due to the different phytogeographical regions (Akata et al., 2018). In this study, Suillus collinitus mushroom collected from Gaziantep/Oğuzeli (Turkey) was used as a material. Suillus collinitus, one of the edible mushrooms, is porous and mostly spreads in pine forests. Cap height is $8-11 \mathrm{~cm}$. Its surface is slippery. Their color is light brown. It has a sour smell and a different taste. It spreads in clusters (Bonfante, 1998).

Antioxidant activity studies previously performed on Suillus species are shown in table 1.

In this study, TAS, TOS, OSI and some element contents of $S$. collinitus mushroom were determined.

\section{Materials and Methods}

Study material $S$. collinitus samples were collected from Oğuzeli/Gaziantep (Turkey). The samples were dried in an oven at $40^{\circ} \mathrm{C} 30 \mathrm{~g}$ of the dry samples was weighed and extracted in the soxhlet apparatus at $50^{\circ} \mathrm{C}$ for about 6 hours (BUCHI Extraction System Model B-811). The dry extract was then concentrated in a rotary evaporator (BUCHI Rotavapor Model R-144).

\section{Determination of Element Content}

$\mathrm{Fe}, \mathrm{Zn}, \mathrm{Cu}, \mathrm{Pb}$ and $\mathrm{Ni}$ contents of $\mathrm{S}$. collinitus were determined by using atomic absorption spectrophotometer device (Agilent 240FS AA). Before reading, the samples were dried at $80^{\circ} \mathrm{C}$ to constant weight. $0.5 \mathrm{~g}$ of the dry 
samples were mineralized using a microwave solubilizer (Milestone Ethos Easy) in a mixture of $9 \mathrm{~mL} \mathrm{HNO3+1}$ $\mathrm{mL} \mathrm{H}_{2} \mathrm{O}_{2}$ (Sevindik and Akata, 2019).

\section{TAS, TOS and OSI Tests}

Total antioxidant status and the total oxidant status of study material Rel Assay brand commercial kits (Rel Assay Kit Diagnostics, Turkey) was used. The calibrator Trolox was used in antioxidant kits. Results are shown in mmol Trolox equiv./L. Calibrator hydrogen peroxide was used in oxidant kits. Results are shown as $\mu$ mol $\mathrm{H}_{2} \mathrm{O}_{2}$ equiv./L (Erel, 2004, 2005). The oxidative stress index was calculated with the formula TOS / (TASx10) (Erel, 2005).

\section{Results and Discussion}

\section{Element Contents}

Fungi play a role in breaking down organic cover in the ecosystem. During the breakdown of the organic cover, they accumulate different levels of elements in their bodies depending on the substrate content they use (Baba et al., 2012; Baba et al., 2020). In our study, the $\mathrm{Fe}, \mathrm{Zn}, \mathrm{Cu}, \mathrm{Pb}$ and $\mathrm{Ni}$ contents of $S$. collinitus were determined. The findings obtained are shown in Table 2.

In previous studies, the levels of elements detected in wild mushrooms have been reported in the literature These values were reported as 14.6-835.0 for Fe, 29.8-158.0 for $\mathrm{Zn}, 71.0-95.0$ for $\mathrm{Cu}, 2.86-6.88$ for $\mathrm{Pb}$ and $1.18-5.14$ for $\mathrm{Ni}$ in $\mathrm{mg} / \mathrm{kg}$ (Vetter, 1990; Sevindik et al., 2017; Krupodorova and Sevindik, 2020). Compared to these values, it was determined that the $\mathrm{Zn}, \mathrm{Cu}$ and $\mathrm{Ni}$ contents of $S$. collinitus were lower than the literature ranges, the $\mathrm{Pb}$ content was higher than the literature ranges, and the Fe levels were within the literature ranges. In this context, it is seen that the element levels of $S$. collinitus are at normal levels.

\section{TAS, TOS and OSI Values}

Living organisms produce reactive oxygen species (ROS) as a result of metabolic activities. While these ROS compounds have a beneficial effect in low amounts, they cause oxidative stress when they reach high levels (Kattoor et al., 2017; Mohammed et al., 2018). As a result of oxidative stress in living things, different diseases such as cardiological disorders, Alzeihmer, Parkinson's and cancer occur (Salim, 2017; Mohammed et al., 2019). The antioxidant defense system plays a role in reducing oxidative stress. In cases where the antioxidant defense system is insufficient, supplementary antioxidant sources are used (Mohammed, 2020). In this study, TAS, TOS and OSI values of Suillus collinitus mushroom were determined. The findings obtained are shown in table 3 .

TAS, TOS and OSI values of $S$. collinitus were not determined in previous studies. There are studies on different mushrooms. In these studies, antioxidant, oxidant and oxidative stress indexes of Cyclocybe cylindracea (TAS: $4.325 \mathrm{mmol} / \mathrm{L}$, TOS: $21.109 \mu \mathrm{mol} / \mathrm{L}$ and OSI: 0.488), Clavariadelphus truncatus (TAS: $2.415 \mathrm{mmol} / \mathrm{L}$, TOS: $3.367 \mu \mathrm{mol} / \mathrm{L}$ and OSI: 0.140), Cerrena unicolor (TAS: $6.706 \mathrm{mmol} / \mathrm{L}$, TOS: $19.308 \mu \mathrm{mol} / \mathrm{L}$ and OSI: 0.288), Infundibulicybe geotropa (TAS: $1.854 \mathrm{mmol} / \mathrm{L}$, TOS: $30.385 \mu \mathrm{mol} / \mathrm{L}$ and OSI: 1.639), Cantharellus cibarius (TAS: $5.268 \mathrm{mmol} / \mathrm{L}$, TOS: $6.380 \mu \mathrm{mol} / \mathrm{L}$ and OSI: 0.121) and Macrolepiota procera (TAS: 2.823 mmol/L, TOS: $10.349 \mu \mathrm{mol} / \mathrm{L}$ and OSI: 0.367) mushrooms were reported (Akgül et al., 2016; Sevindik 2018b; Sevindik 2018b; Sevindik et al., 2018; Sevindik 2019; Sevindik et al., 2020). Compared to these studies, the TAS value of $S$. collinitus was higher than $C$. truncatus and $I$. geotropa and lower than C. cylindracea, C. unicolor, $C$. cibarius and $M$. procera mushrooms. TAS value indicates the whole of the antioxidant compounds produced in the living organisms (Mohammed et al., 2018). It was determined that $S$. collinitus used in our study has antioxidant potential. The TOS value indicates the whole of the oxidant compounds produced in the living organisms (Mohammed et al., 2019). The TOS value of S. collinitus was higher than C. truncatus, C. cibarius, M. procera, and lower than C. cylindracea, C. unicolor, I. geotropa mushrooms. In this context, $S$. collinitus is recommended to be consumed more carefully due to its high TOS values. The OSI value shows how much the fungus suppresses endogenous antioxidant and endogenous oxidant compounds (Mohammed et al., 2020). When we look at the OSI value of $S$. collinitus, it was found that it was higher than C. cylindracea, C. truncatus, C. unicolor, C. cibarius, $M$. procera mushrooms and lower than I. geotropa. As a result, it was determined that $S$. collinitus has antioxidant potential.

Table 1. Antioxidant activities of Suillus species

\begin{tabular}{l|c}
\hline \multicolumn{1}{c|}{ Suillus species } & References \\
\hline $\begin{array}{l}\text { Suillus aeruginascens } \\
\text { Suillus bellini }\end{array}$ Macáková et al., 2009; \\
$\begin{array}{l}\text { Suillus bovinus } \text { collinitus } \\
\text { Suillus granulates }\end{array}$ & Ribeiro et al., 2006; Kalogeropoulos et al., 2013; \\
Suillus granulatus & Robaszkiewicz et al., 2010; \\
Suillus grevillei & Akata et al., 2012; Heleno et al., 2010; \\
Suillus lakei & Macáková et al., 2009; Ribeiro et al.,2006 \\
Suillus luteus & Ribeiro et al., 2006; Reis et al., 2014; Tel et al., 2014; Zhou et al., 2016; Chen et al., 2018; \\
Suillus luteus & Mushtaq et al., 2020; \\
Suillus mediterraneensis & Macáková et al., 2009 \\
Suillus placidus & Barranco et al., 2010; \\
Suillus variegates & Ribeiro et al., 2006; Macáková et al., 2009; Barranco et al., 2010; Jaworska et al., 2014; \\
\hline
\end{tabular}


Table 2. Element Levels of S. collinitus

\begin{tabular}{|c|c|c|c|c|c|}
\hline Elements & $\mathrm{Fe}$ & $\mathrm{Zn}$ & $\mathrm{Cu}$ & $\mathrm{Pb}$ & $\mathrm{Ni}$ \\
\hline S. collinitus & $350.72 \pm 10.23$ & $10.46 \pm 1.28$ & $68.11 \pm 2.51$ & $11.58 \pm 2.43$ & $1.47 \pm 0.21$ \\
\hline \multicolumn{6}{|c|}{ Values are presented as mean \pm S.D, $n=3$ (Experiments were made as 3 parallel) } \\
\hline \multicolumn{6}{|c|}{ Table 3. TAS, TOS ve OSI Values } \\
\hline Material & TAS & & TOS & \multicolumn{2}{|c|}{ OSI } \\
\hline S. collinitus & $2.467 \pm 0$ & & $17.845 \pm 0.273$ & \multicolumn{2}{|c|}{$0.677 \pm 0.030$} \\
\hline
\end{tabular}

Values are presented as mean \pm S.D.; $n=6$ (Experiments were made as 5 parallel)

\section{Conclusion}

In this study, the antioxidant activity of $S$. collinitus and the levels of some elements were determined. As a result of the studies, it has been determined that the mushroom has antioxidant potential. Element levels were found to be at normal levels according to the stated literature values.

\section{References}

Akata I, Ergonul B, Kalyoncu F. 2012. Chemical compositions and antioxidant activities of 16 wild edible mushroom species grown in Anatolia. International Journal of Pharmacology, 8(2): 134-138.

Akata I, Kabaktepe Ş, Sevindik M, Akgül H. 2018. Macrofungi determined in Yuvacık Basin (Kocaeli) and its close environs. Kastamonu Üniversitesi Orman Fakültesi Dergisi, 18(2): 152-163.

Akgul H, Sevindik M, Coban C, Alli H, Selamoglu Z. 2017. New approaches in traditional and complementary alternative medicine practices: Auricularia auricula and Trametes versicolor. J Tradit Med Clin Natur, 6(2): 239.

Akgül H, Sevindik M, Akata I, Altuntaş D, Bal C, Doğan M. 2016. Macrolepiota procera (Scop.) Singer. Mantarının Ağır Metal İçeriklerinin ve Oksidatif Stres Durumunun Belirlenmesi. Süleyman Demirel Üniversitesi Fen Bilimleri Enstitüsü Dergisi, 20(3): 504-508.

Arpaz F, Güler P, Türk M. 2017. Suillus collinitus (Fr.) Kuntze'un Sitotoksite, Apoptik ve Nekrotik Etkileri. Life Sciences, 12(4): 56-63.

Baba H, Ergün N, Özçubukçu S. 2012. Antakya (Hatay)'dan toplanan bazı makrofungus türlerinde ağır metal birikimi ve mineral tayini. Research Journal of Biology Sciences, 5(1): 56.

Baba H, Sevindik M, Dogan M, Akgul H. 2020. Antıxıdant, Antımicrobial Actıvities And Heavy Metal Contents of Some Myxomycetes. Fresenius Environmental Bulletin, 29(09): 7840-7846

Bal C, Akgul H, Sevindik M, Akata I, Yumrutas O. 2017. Determination of the anti-oxidative activities of six mushrooms. Fresenius Envir Bull, 26(10): 6246-6252.

Barranco PG, Ocanas LG, Cabrera LV, Carmona MCS, Ocanas FG, Gomez XSR, Rangel RL. 2010. Evaluation of antioxidant, immunomodulating, cytotoxic and antimicrobial properties of different strains of Basidiomycetes from Northeastern Mexico. Journal of Medicinal Plants Research, 4(17): 1762-1769.

Bonfante P, Balestrini R, Martino, E, Perotto S, Plassard C, Mousain D. 1998. Morphological analysis of early contacts between pine roots and two ectomycorrhizal Suillus strains. Mycorrhiza, 8(1): 1-10.

Chen S, Su T, Wang Z. 2018. Structural characterization, antioxidant activity, and immunological activity in vitro of polysaccharides from fruiting bodies of Suillus granulatus. Journal of food biochemistry, 42(3): e12515.

Erel O. 2004. A novel automated direct measurement method for total antioxidant capacity using a new generation, more stable ABTS radical cation. Clinical biochemistry, 37(4): 277-285.
Erel O. 2005. A new automated colorimetric method for measuring total oxidant status. Clinical biochemistry, 38(12): 1103-1111.

Gürgen A, Sevindik M, Yıldız S, Akgül H. 2020. Determination of Antioxidant and Oxidant Potentials of Pleurotus citrinopileatus Mushroom Cultivated on Various Substrates. Kahramanmaraş Sütçü İmam Üniversitesi Tarım ve Doğa Dergisi, 23(3): 586591.

Heleno SA, Barros L, Sousa MJ, Martins A, Ferreira IC. 2010. Tocopherols composition of Portuguese wild mushrooms with antioxidant capacity. Food Chemistry, 119(4): 1443-1450.

Jaworska G, Pogoń K, Bernaś E, Skrzypczak A, Kapusta I. 2014. Vitamins, phenolics and antioxidant activity of culinary prepared Suillus luteus (L.) Roussel mushroom. LWT-Food Science and Technology, 59(2): 701-706.

Kattoor AJ, Pothineni NVK, Palagiri D, Mehta JL. 2017. Oxidative stress in atherosclerosis. Current atherosclerosis reports, 19(11): 42.

Keleş A, Koca I, Gençcelep H. 2011. Antioxidant properties of wild edible mushrooms. Journal of Food Processing \& Technology, 2(6): 2-6.

Kikuchi T, Motoyashiki N, Yamada T, Shibatani K, Ninomiya K, Morikawa T, Tanaka R. 2017. Ergostane-type sterols from king trumpet mushroom (Pleurotus eryngii) and their inhibitory effects on aromatase. International journal of molecular sciences, 18(11): 2479.

Krupodorova T, Sevindik M. 2020. Antioxidant Potential and Some Mineral Contents of Wild Edible Mushroom Ramaria stricta. AgroLife Scientific Journal, 9(1): 186-191

Macáková K, Opletal L, Polášek M, Samková V, Jahodáŕ L. 2009. Free-radical scavenging activity of some European Boletales. Natural product communications, 4(2): 1934578X09004002 19.

Mohammed FS. 2020. Phenolic Contents, Antioxidant and Antimicrobial Activities of Allium stamineum Collected from Duhok (Iraq). Fresenius Environmental Bulletin, 29(09): 75267531

Mohammed FS, Akgul H, Sevindik M, Khaled BMT. 2018. Phenolic content and biological activities of Rhus coriaria var. zebaria. Fresenius Environmental Bulletin, 27(8): 5694-5702.

Mohammed FS, Daştan T, Sevindik M, Selamoglu Z. 2019. Antioxidant, antimicrobial activity and therapeutic profile of Satureja hortensis from Erzincan Province. Cumhuriyet Tip Dergisi, 41(3): 558-562.

Mohammed FS, Şabik AE, Sevindik E, Pehlivan M, Sevindik M. 2020. Determination of Antioxidant and Oxidant Potentials of Thymbra spicata Collected from Duhok-Iraq. Turkish Journal of Agriculture-Food Science and Technology, 8(5): 1171-1173.

Mushtaq W, Baba, H, Akata İ, Sevindik M. 2020. Antioxidant Potential and Element Contents of Wild Edible Mushroom Suillus granulatus. Kahramanmaraş Sütçü İmam Üniversitesi Tarım ve Doğa Dergisi, 23(3): 592-595.

Reis FS, Stojković D, Barros L, Glamočlija J, Ćirić A, Soković M, Ferreira IC. 2014. Can Suillus granulatus (L.) Roussel be classified as a functional food? Food and function, 5(11): 28612869. 
Ribeiro B, Rangel J, Valentão P, Baptista P, Seabra RM, Andrade PB. 2006. Contents of carboxylic acids and two phenolics and antioxidant activity of dried Portuguese wild edible mushrooms. Journal of agricultural and food chemistry, 54(22): 8530-8537.

Robaszkiewicz A, Bartosz G, Ławrynowicz M, Soszyński M. 2010. The Role of Polyphenols, $\beta$-Carotene, and Lycopene in the Antioxidative Action of the Extracts of Dried, Edible Mushrooms. Journal of nutrition and metabolism, 2010. https://dx.doi.org/ 10.1155/2010/173274

Salim S. 2017. Oxidative stress and the central nervous system. Journal of Pharmacology and Experimental Therapeutics, 360(1): 201-205.

Sevindik M. 2018a. Investigation of antioxidant/oxidant status and antimicrobial activities of Lentinus tigrinus. Advances in pharmacological sciences, 2018. https://doi.org/10.1155/ 2018/1718025

Sevindik M. 2018b. Investigation of Oxidant and Antioxidant Status of Edible Mushroom Clavariadelphus truncatus. Mantar Dergisi, 9(2): 165-168.

Sevindik M. 2018c. Antioxidant and antimicrobial activity of Cerrena unicolor. Mycopath, 16(1): 11-14

Sevindik M. 2019. Wild Edible Mushroom Cantharellus cibarius as a Natural Antioxidant Food. Turkish Journal of Agriculture-Food Science and Technology, 7(9): 1377-1381.

Sevindik M, Akgul H, Akata I, Alli H, Selamoglu Z. 2017. Fomitopsis pinicola in healthful dietary approach and their therapeutic potentials. Acta alimentaria, 46(4): 464-469.
Sevindik M, Akgul H, Bal C, Selamoglu Z. 2018. Phenolic contents, oxidant/antioxidant potential and heavy metal levels in Cyclocybe cylindracea. Indian Journal of Pharmaceutical Education and Research, 52(3): 437-441.

Sevindik M, Akgul H, Selamoglu Z, Braidy N. 2020. Antioxidant and Antigenotoxic Potential of Infundibulicybe geotropa Mushroom Collected from Northwestern Turkey. Oxidative Medicine and Cellular Longevity, 2020. https://doi.org/10. 1155/2020/5620484

Sriramulu M, Sumathi S. 2017. Photocatalytic, antioxidant, antibacterial and anti-inflammatory activity of silver nanoparticles synthesised using forest and edible mushroom. Advances in Natural Sciences: Nanoscience and Nanotechnology, 8(4): 045012.

Tel G, Deveci E, Küçükaydın S, Özler MA, Duru ME, Harmandar M. 2014. Evaluation of antioxidant activity of Armillaria tabescens, Leucopaxillus gentianeus and Suillus granulatus: The mushroom species from Anatolia. Eurasian Journal of Analytical Chemistry, 8(3): 136-147.

Vetter J. 1990. Mineral element content of edible and poisonous macrofungi. Acta Alimentaria, 19(1): 27- 40.

Wang Y, Tian Y, Shao J, Shu X, Jia J, Ren X, Guan Y. 2018. Macrophage immunomodulatory activity of the polysaccharide isolated from Collybia radicata mushroom. International journal of biological macromolecules, 108: 300306.

Zhou F, Yan S, Chen S, Gong L, Su T, Wang Z. 2016. Optimization extraction process of polysaccharides from Suillus granulatus and their antioxidant and immunological activities In vitro. Pharmacognosy Magazine, 12(Suppl 2): S277. 